\title{
The role of women in artisanal fishing on the Oléria River, Marajó archipelago, Brazil
}

O papel das mulheres na pesca artesanal no rio Oléria, arquipélago do Marajó, Brasil

El papel de la mujer en la pesca artesanal en el río Oléria, archipiélago de Marajó, Brasil

\begin{abstract}
Fishing women in Brazil are still "invisible" in the eyes of contemporary society. It is with this perspective, that this work analyzed the role of riverside women in artisanal fishing in the Marajó archipelago (state of Pará, Brazil). The research was carried out in the Santo Antônio community in the municipality of Breves, located on the Oléria river. The methodological procedure used was bibliographic research and questionnaires with twenty women who practice fishing along this river. Data collection took place in January 2020. The information was analyzed using a simple description. The research revealed that even though women engaged in various fishing-related activities, they are usually represented by their husbands or children and their activity is seen as an aid. Therefore, there is a need for these women to have greater visibility so that Marajoara society can value them once their work in artisanal fishing is fundamental for their subsistence and that of their social group.
\end{abstract}

Keywords: Amazon; Extractivism; Genre; Subsistence; Fisherwomen.

\section{Resumo}

As mulheres pescadoras no Brasil ainda estão "invisíveis" aos olhos da sociedade contemporânea. É com essa perspectiva, que este trabalho analisou o papel das mulheres ribeirinhas na pesca artesanal no arquipélago do Marajó (estado do Pará, Brasil). A pesquisa foi realizada na comunidade Santo Antônio, no município de Breves, situada no rio Oléria. O procedimento metodológico utilizado foi a pesquisa bibliográfica e aplicação de questionários com vinte mulheres que praticam a pesca ao longo desse rio. A coleta de dados ocorreu em janeiro de 2020 . As informações foram analisadas utilizando uma descrição simples. A pesquisa revelou que mesmo as mulheres desenvolvendo várias atividades relacionadas a pesca elas aparecem normalmente representadas pelos maridos ou filhos e sua atividade é vista como uma ajuda. Portanto, há necessidade dessas mulheres terem maior visibilidade de forma que a sociedade marajoara possa valorizá-las, pois seu trabalho na pesca artesanal é fundamental para sua subsistência e de seu grupo social.

Palavras-chave: Amazônia; Extrativismo; Gênero; Subsistência; Pescadoras.

\section{Resumen}

Las mujeres pesqueras en Brasil siguen siendo "invisibles" a los ojos de la sociedad contemporánea. Es con esta perspectiva que este trabajo analiza el papel de las mujeres ribereñas en la pesca artesanal en el archipiélago de Marajó (estado de Pará, Brasil). La investigación se realizó en la comunidad de Santo Antônio, en el municipio de Breves, ubicado sobre el río Oléria. El procedimiento metodológico utilizado fue la investigación bibliográfica y cuestionarios con veinte mujeres que practican la pesca en este río. La recopilación de datos tuvo lugar en enero de 2020. La información se analizó mediante una descripción sencilla. La investigación reveló que incluso las mujeres que realizan diversas actividades relacionadas con la pesca, suelen estar representadas por sus maridos o hijos y su 
actividad es vista como una ayuda. Por ello, es necesario que estas mujeres tengan una mayor visibilidad para que la sociedad Marajoara pueda valorarlas, pues su labor en la pesca artesanal es fundamental para su subsistencia y la de su grupo social.

Palabras clave: Amazonas; Extractivismo; Género; Subsistencia; Pescadores.

\section{Introduction}

The term "fish" designates any food that can be taken from oceanic or inland waters (sweet or brackish) (Soares; Gonçalves, 2012). Used in human food, such as fish, molluscs, crustaceans, amphibians, turtles, among others (Gonçalves, 2011). The supply of fish in the world has been fed in a slice by fishing (FAO, 2018). In Brazil, fishing has been a traditional activity since the pre-Cabral period (Lima et al., 2016).

In the northern region of Brazil, especially in the Amazon, fishing is an important activity, as a source of food for the riverside peoples. It is worth mentioning that a large part of the livelihood of these peoples comes from artisanal fishing (Caetano \& Silva, 2016). Most fishermen in the Amazon region are artisanal (Isaac \& Barthem, 1995). For Martins \& Alvim (2016), fishing is an activity that has been carried out predominantly by men. However, this is not the reality of all regions, it only shows the Brazilian social imaginary, in which this activity predominates the male gender.In the Marajó archipelago (state of Pará, Brazil), this imagery is present in most municipalities and ends up making women who also practice fishing and aquaculture invisible (Costa et al., 2020). Through preliminary evaluations, we noticed that in the municipality of Breves there is the fishing of Amazonian shrimp, Macrobrachium amazonicum (Heller, 1862) and tambaqui, Colossoma macropomum (Cuvier, 1818), in several rural communities, such as Santo Antônio, on the river Oléria.

It is worth considering that these aquatic organisms are also fished by women in Marajó. Although their activities are not recognized as work, many Marajoara women engage in fishing in the Amazon (Oliveira \& Florentino, 2018; Costa et al., 2020; Silva et al., 2020). Thus, such activities that they carry out range from fishing / breeding, through processing to commercialization.

The gender relation is imperative to the understanding of artisanal fishing in Marajó. It is perceived that the spaces and roles that men and women occupy in this activity can be understood from it. Several studies address the participation of women in activities related to the field, such as: in agriculture (Ball, 2020; Khatri-Chhetri et al., 2020; Tsige et al., 2020), in aquaculture (Martins \& Alvim, 2016; Shah \& Bukhari, 2019; Gopal et al., 2020; Costa et al., 2020) and in fishing (Silva et al., 2019; Harper et al., 2020; Nunan \& Cepić, 2020). Therefore, there is little research on the participation of women in artisanal fishing in Marajó, in the Amazon region.

Thus, the objective of this work was to analyze the role of riverside women in artisanal fishing in the Oléria river, Marajó archipelago (Pará state, Brazil).

\section{Methodology}

\subsection{Study area}

The research was conducted in the Santo Antônio community, on the Oléria river, in the rural area of the municipality of Breves, Marajó archipelago, Pará, Brazil. Marajó is located on the Amazon coast (Amaral et al., 2012). It is a region rich in water resources and socio-biodiversity (Costa, 2016). The archipelago has three geographic microregions: Arari, Furos de Breves and Portel (Calvis et al., 2016; IBGE, 2010). It has a total of 16 municipalities: Cachoeira do Arari, Chaves, Muaná, Ponta de Pedras, Salvaterra, Santa Cruz do Arari and Soure, Afuá, Anajás, Breves, Curralinho and São Sebastião da Boa Vista, Bagre, Gurupá, Melgaço and Portel.

The municipality of Breves is located southwest of Marajó, with a territorial extension of 9,550.474 km² (IBGE, 
2010). The majority of this population is riverside living from fishing, extractivism, aquaculture and family farming. Access to the Santo Antônio community is only by river, by boat, motorboat or tail. A trip that lasts approximately three hours.

\subsection{Data collect}

The methodological path was based on qualitative research. It was exploratory in nature and had bibliographical and documentary research as its basic procedures. The qualitative method promotes openness, flexibility, the ability to observe and interact with the group of investigated and social subjects involved as fundamental ways (Mynaio, 2004). This method also contributes to understanding the beliefs, attitudes and values of certain social groups (Gaskell, 2008). Qualitative, the data presented are part of an exploratory research. They were obtained through the application of questionnaires with twenty women who practice artisanal fishing on the Oléria river, Santo Antônio community.

The interview script consisted of questions such as: gender, place of birth, marital status, age, number of people per residence, number of children, time residing in the locality, education level, type of fishing, work relationships and other information relevant to the research. The questions were designed according to the research objectives, in line with the data collected in the literature (Brugere \& Williams, 2017; Farquhar et al., 2018; Shah \& Bukhari, 2019; Gopal et al., 2020). A case study was carried out, as it helps to understand individual, group, social, political and cultural facts, in addition to allowing researchers to understand contemporary events in a deeper way (Yin, 2010).

\subsection{Ethical considerations}

The research sought to adopt ethical procedures, respecting the subjects participating in the work. Thus, the consent of the people who took part in the study was obtained. An Informed Consent Form (ICF) was also used, which was signed by the interviewees. This document requested authorization to carry out this research.

\subsection{Data analysis}

Data analysis is an important research step. It is a process of knowledge production that consisted of making sense of the documents or interviews / questionnaires that were collected (Creswell, 2007). The following discussions refer only to a stratum of the amount of data systematized during fieldwork. Therefore, the results reflect, above all, the view on the participation of riverside women in artisanal fishing.

\section{Results and Discussion}

\subsection{The invisibility of women in fishing}

We observed that on the Oléria River, women have been developing artisanal fishing activities over the years. However, in traditional historiography, only men are identified as fishermen. While the women are relegated to secondary services related to fishing. Thus, we must consider that women have always developed many activities in fishing (Simonian, 2005). For Silva et al. (2019) working with women in the municipality of Vigia de Nazaré, in Pará, highlight that they act both directly and indirectly, for the success of fishing activities. In the municipalities of Marajó it is no different, fishing is also an activity carried out by them.

Thus, their performance in this space occurs, with rare exceptions, in a context of invisibility and devaluation of their work. It is noticed that most of the time as an extension of domestic tasks and not as fishing activity (Matins \& Alvim, 2016). A careful look will reveal that in the Santo Antônio community, artisanal fishing is carried out predominantly by men. However, further research will show that both men and women play key roles in this activity for the municipality. It is worth 
noting that in peasant or riverside societies women do not abandon domestic tasks. They incorporate more activities which are fundamental to their livelihood and that of their social group (Neves \& Medeiros, 2013).

For Martins and Alvim (2016) they carry out various activities, especially those related to the fishing sector. Women on the Oléria River are not exempt from their domestic obligations, such as childcare, washing clothes and dishes, cooking, among others. They perform various tasks, and tend to multidirect them, since their working hours are longer (Begum, 2011). Thus, in the studied community they end up combining domestic and productive activities. While men generally focus on one or two activities, such as fishing and agriculture in Marajó. This means that there is an increase in the working hours of these women in order to be able to carry out productive and unproductive activities (Costa et al., 2020).

In the Santo Antônio community, the invisibility of women in fishing activities is directly related to the Brazilian social imagination. With regard to the places and roles that women occupy in society, which considers men as the head of the family and decision makers and women as responsible for domestic tasks. Results similar to this research were shown by Maneschy and Álvares (2010), in the fishing sector in the North and Northeast regions of Brazil. They emphasized that the activities carried out by women are not seen as fishing, as they spend more time on land, and, in the same way, the products captured by them are not considered to be caught.

Similar results to the present study, were evidenced in the research by Rahman and Tasnim (2019). They point out that in Bangladesh fishing is seen as a male domain and the contribution of women is rarely recognized. Maneschy (1995) points out that in Pará, even though women play important roles in fishing, their work is still seen as help, thus prevailing gender inequality in this activity. We observed that both in fishing and in aquaculture, the male gender always comes first, while they are seen only activity helpers. Ndanga et al. (2013), reports that in Kenya, the roles played by women in aquaculture production are significant, but are still under-recognized or "hidden" in the analysis of the aquaculture value chain. Costa et al. (2020) report that the participation of women is important for the development of aquaculture activities in the Marajó archipelago.

It is important to highlight that the participation of women in various productive and unproductive activities is essential to ensure the livelihood of their social group. However, historiography for a long time made their struggle and participation in various societies invisible. In this way, they were left out of historical reports as if they were unaware of the facts (Perrot, 2015). Many of them have always carried out activities together with their spouses in the fields, fishing, vegetable and animal extraction, among others. However, his work is seen as an aid, since the domain of productive activities, in terms of classification, is man's space (Wedig \& Menasche, 2013).

Thus, researching and debating artisanal fishing in Marajó is also about discussing gender relations. An activity carried out by male women, who are essential to ensure subsistence (Bruger \& Williams, 2017). However, the roles that each one plays still do not have the same recognition in the region. therefore, it is important to debate and research that reveals the female presence in fishing and aquaculture in the rivers of Marajó, and elsewhere in Brazil.

\subsection{Socioeconomic aspects of fisherwomen}

Most of the communities in Marajó emerged along the rivers, with Santo Antônio formed along the Oleria River. In the Amazon, rivers have always been fundamental to the occupation process, as they are the main access and communication routes in this region (Castro, 2008). According to residents of the studied community, the base of the economy is extraction, which is practiced in different environments such as the river, land and lowland. Thus, they had to acquire knowledge about these places and the territory, in addition to appropriate techniques to ensure the management of the resources existing in the territory and guarantee their livelihood. 
The age group of fisherwomen in the Santo Antônio do Oléria river varies between 20 and 41 years of age. Many of these women have fishing as one of the professions that guarantee their livelihood. We realized that they practice tambaqui and prawn-da-Amazônia fishing, both happen by hand, with the participation of family labor. Other catches are also caught, such as aracú (Leporinus freiderici), hake (Cynoscion acoupa), mandubé (Ageneiosus brevifilis), sardines (Sardinella brasiliensis) and jejú (Hoplias malabaricus). Most of these fish are for subsistence and the surplus is sold in the community itself or at the public fair / market in Breves. During fishing, rowing and motorized canoes are used. This type of vessel is widely used by the Marajoara people, as it is faster and facilitates daily activities.

Family farming is also another activity practiced by women in the Santo Antônio community. They work on planting cassava, both for domestic consumption and for commercialization. This product is grown for the production of tapioca flour, water flour and tapioca flour (Guedes, 2018). The preparation of the flours is carried out collectively and the tasks are divided among all members of the family, thus men and women, and even children perform activities such as peeling the cassava, preparing the dough, toasting the flour, among others.

In the present study, in general women and men are involved in family activities. In this sense, it is the family that defined all the tasks related to the activities of fishing, agriculture and plant extraction, for each member of the group. Women are also the guardians of the traditional knowledge and culture of these peoples, such knowledge is fundamental to production and extraction. The people living in and from the forest produced complex forms of occupation (Gomes, 2015). They would build their territories, their territorialities and their material culture based on the collective management of the resources existing in their territories. Results similar to the present study were reported by Arêda-Oshai (2017), in Salvaterra, in Marajó dos Campos. The author describes that in several communities the work is carried out by all members of the family. Thus, in these communities in Marajó there is a family sub-nucleus with the function of reinforcing the social protection network.

We observed that families in the community have an average minimum wage. However, not all families manage to earn this amount per month. Thus, they tried to develop some strategies to ensure the subsistence of the family nucleus, among which fishing, the collection of açaí (Euterpe oleracea Mart.), Pupunha (Bactris gasipaes Kunth) and seeds stand out. In addition, to seek access to public policies such as family allowance, retirement, among others to ensure their livelihood and that of the social group. In the community, most of the extraction of seeds such as andiroba (Carapa guianensis Aubl.) Is performed by women. Thus, they collect the seeds in the forest and store them in straw baskets, for later oil extraction.

Generally, oil extraction from this vegetable is a task performed by women, which requires specific knowledge and a large amount of seeds. They learned to extract oil from their ancestors and this knowledge has been passed down from generation to generation. However, not all people who live there know the process of extracting the vegetable, as it is not an easy task. Most of the oil production is for the consumption of the people of the community, because the oil of this vegetable is widely used by riverside people in the treatment of various types of diseases, only a small amount of the production is sold in the municipality of Breves.

\subsection{The particularities of fishing on the Oléria River}

The work of women living in the Santa Antônio community reaches all stages of fishing. Thus, they are present in the construction of vessels and traps to capture shrimp and fish. They operate in the capture, processing and marketing of fish. We observed that matapi is the fishing art most used by them, this art is also built by women from the community. For the construction of the matapi, they need to remove the vine and the splint that are found in the forest. The baits are usually also prepared by the riverside women to capture the shrimp, for the preparation of these baits they use babassu coconut bran, after which the baits are placed within that art, to attract the shrimp. Among the techniques frequently used in fish fishing are line 
and hook fishing, with puçá, among others. In this perspective, riverside women built and rebuilt strategies for living in and in the forest in a way that they manage to withdraw their livelihood and transmit traditional knowledge from generation to generation.

In the Santo Antônio community, the presence of women in the fishing sector is notorious. They act directly in the capture of fish and/or shrimp, in the processing and commercialization of these products, in addition to being present in the preparation of baits, in the repair of boats and canoes. Our results were similar to those reported by Martins and Alvim (2016), in the Beto community, in Sergipe. The authors consider that women participate in all stages of activities related to fishing, that is, from capture to commercialization.

Many women in the studied community reported that they go out fishing alone, in the company of other women or their families. They also state that sometimes this activity is carried out during the day or night, in the region. In this way, they are directly linked to the sector both in the production and in the commercialization of the fish. This result was also similar to that of Guedes (2018) when showing that women from the Santa Rita de Barreira quilombo, in São Miguel do Guamá, Pará also perform artisanal fishing, and that they carry out all activities alone.

The fishing modality used in the studied community is artisanal fishing. They use traditional fishing techniques and small boats. This practice presents low profit and income, but contributes to the food security of local families. Costa et al. (2020), highlight the importance of training courses in fishing and aquaculture, for women in Marajó. Such courses can contribute to increase the productivity of these peoples and to ensure their food sovereignty. We realize the importance of social organizations, such as associations and cooperatives in the region, to fight for public policies and for training for the population. For Amachree et al. (2019) membership in the association or cooperative can help fishermen to meet and have access to government funding, as well as technical training.

The involvement of the Marajoara woman in fishing is essential, as it is often she who leads the boat or canoe for her husband or son, pulls the fish net or assists her husband in pulling and sets the trap to catch the shrimp. In this sense, the roles played by women in fishing are relevant. However, it is still viewed in a secondary way, even by them. Thus, the activities they carry out are seen as "help" or "supplementation" of income. However, their work is not just a help, but essential for their livelihood and that of their social group. Therefore, it is necessary to decolonize the social imaginary about artisanal fishing in Marajó. From this, the work of these women will be recognized and valued, so that they have visibility both in the region and in the country.

Fishing is not the only productive activity performed by women in the studied community. A result similar to this research was also reported by Costa et al. (2020) working with women in aquaculture in the Marajó archipelago, show that women in this region need to perform various productive activities to guarantee their livelihood. In the present study, fishing is a very old activity in the region and has always been important for the survival of riverside peoples. Thus, fishing, extractivism and agriculture are present in the daily lives of women in the Santo Antônio community. Thus, the fish is traded together with the flour and some seeds collected in the forest.

We can infer that the women of Marajó, in addition to being important in all stages of the fishing sector, they also perform other productive activities that are also important for their livelihood and for their social group. Which means, that they share the same work spaces with men, most of the time there is no differentiation between the tasks performed between them.

\section{Conclusion}

To understand women as artisanal fishermen in the Santo Antônio community on the Oléria river, in Breves (Marajó, 
Brazil), is to value history and spaces. The roles and functions they occupy in the region are important in the social, economic and cultural aspects. Women play fundamental roles in the subsistence and well-being of social groups, especially when it comes to activities related to artisanal fishing. Many of them are guardians of traditional knowledge related to fishing in the community. Even developing different functions and important roles, yet perceives the work as "help" or supplementary income. The participation of women in the Amazon is still made invisible in fishing. In this perspective, this study reinforces their importance in society, for subsistence and for the social group, while highlighting due visibility.

\section{Acknowledgments}

To students of the Technical course in Aquaculture at the Federal Institute of Education, Science and Technology of Pará (IFPA), Campus Breves (Cristina Correa, Fernanda Silva, Igor Fialho, Helliton Cunha, Luan Souza and Railane Barbosa), for their contribution to the field research.

\section{References}

Amachree, D., Jamabo, N., \& Joseph, D. E. (2019). Socio-economic characteristics of small-scale catfish farming enterprise in Obio/Akpor Local Government Area, Rivers State, Nigeria. International Journal of Fisheries and Aquaculture, 11(3), 62-71.

Amaral, D. D., Mantelli L. R., \& Rossetti, D. F. (2012). Paleoenvironmental control on modern forest composition of southwestern Marajo Island, Eastern Amazonia. Water and Environment Journal, 26: 70-84.

Arêda-Oshai, C. M. (2017). "Não é só médico que cura, não é só a Medicina que cura": perspectivas sobre saúde entre Coletivos Quilombolas no MarajóPará/Brasil. 2017. Tese (Doutorado em Antropologia) - Universidade Federal do Pará, 2017.

Ball, J. A. (2020). Women farmers in developed countries: a literature review. Agriculture and Human Values, 37, $147-160$.

Batista, V. S.; Inhamuns, A. J.; Freitas, C. E. C.; \& Freire-Brasil, D. (1998). Characterization of the fishery in riverine communities in the LowSolimões/HighAmazon region. In: Fishery Management and Ecology, p. 101-117.

Begum, J. (2011). La mujer, el medio ambiente y el desarrollo sostenible: estableciendo los vínculos. In: Programa das Nações Unidas Para o Meio Ambiente. La mujer y el Medio Ambiente. PNUMA; United Nations Fundation, p. 14-37.

Brugere, C., \& Williams, M. (2017). Profile: Women in Aquaculture. Disponível em: https://genderaquafish.org/portfolio/women-in-aquaculture/. Acesso em: $06 / 04 / 2020$.

Caetano, V. N. S.; \& Silva, A. N. (2016). Desenvolvimento e educação no Marajó: estudo de caso no município de Breves (Marajó/Pará/Brasil). In: Revista GeoAmazônia: Belém, 04(7), 120-137.

Calvis, M. F.; Carvalho, J. P. L.; Cruz, B. E. V.; Gomes, D. L.; Nascimento, E. C.; \& Reis, C. (2016). A influência do Programa Bolsa Família nas práticas alimentares das famílias do Território do Marajó, Pará, Brasil. Revista Scientia Plena, 12(6), 1-11.

Castro, E. (2008). Urbanização, pluralidades e singularidades das cidades amazônicas. In: Castro, E. (Org.). Cidades na floresta. Annablume.

Costa, E. M. (2016). Dos indígenas, os artefatos: a história dos povos indígenas do Arquipélago do Marajó, PA. Revista de Estudos Linguísticos, Literários, Culturais e da Contemporaneidade. Número Especial 18b - 03, 144-154.

Costa, F. P.; Silva, F. N. L.; Guedes, A. C. B.; Passos, P. H. S.; Quadros, M. L. A.; Mendonca, R. C.; \& Oliveira, L. C. (2020). Mulheres na aquicultura: um estudo de caso no arquipélago do Marajó, Brasil. Research, Society and Development, 9(7).

Creswell, J. W. (2007). Projeto de pesquisa: métodos qualitativo, quantitativo e misto. (2a ed.), Artmed.

Gaskell, G. (2008). Entrevistas individuais e grupais. In: Pesquisa qualitativa com texto: imagem e som:um manual prático. Bauer, M. W.; Gaskell, G. (editores), (7a ed.), Vozes.

Gomes, F. S. (2015). Mocambos e Quilombos: uma história do campesinato negro no Brasil. Claro Enigma.

Gopal, N., Hapke, H. M., Kusakabe, K., Rajaratnam, S., \& Williams, M. J. (2020). Expandir os horizontes para as mulheres na pesca e na aquicultura. Gênero, Tecnologia e Desenvolvimento, 1-9.

Guedes, A. C. B. (2018). Mulheres quilombolas e uso de plantas medicinais: práticas de cura em Santa Rita de Barreira/PA. 2018. Dissertação (Mestrado em Desenvolvimento Sustentável do Trópico Úmido) - Universidade Federal do Pará.

Harper, S., Adshade, M., Lam, V. W. Y., Pauly, D., \& Sumaila, U. R. (2020) Valuing invisible catches: Estimating the global contribution by women to smallscale marine capture fisheries production. PLoS ONE, 15(3): e0228912. 
Isaac, V. J.; \& Barthem, R. B. (1995). Os Recursos Pesqueiros da Amazônia Brasileira. In: Boletim Museu Paraense Emilio Goeldi, Antropologia, p. 11: 295339.

Khatri-Chhetri, A., Regmi, P. P., Chanana, N., \& Aggarwal, P. K. (2019). Potential of climate-smart agriculture in reducing women farmers' drudgery in high climatic risk areas. Climatic Change.

Lima, M. A. L.; Freitas, C. E. C.; Moraes, S. M.; \& Doria, C. R. C. (2016). Pesca artesanal no município de Humaitá, médio rio madeira, Amazonas, Brasil. Boletim do Instituto de Pesca, 42(4): 914-923.

Maneschy, M. C. (1995). A mulher está se afastando da pesca? Continuidade no papel da mulher na manutenção doméstica entre famílias de pescadores no litoral do Pará. Boletim do Museu Paraense Emílio Goeldi, série Antropologia, Belém, 11(2), 145-166.

Maneschy, M. C.; \& Álvares, M. L. M. (2010). Mulheres na pesca: trabalho e lutas por reconhecimento em diferentes contextos. Coletiva, Recife, n. 1.

Martins, M. L. S.; \& Alvim, R. G. (2016). Perspectivas do trabalho feminino na pesca artesanal: particularidades da comunidade Ilha do Beto, Sergipe, Brasil. Boletim do Museu Paraense Emílio Goeldi. Belém, 11(2), 379-390.

Minayo, M. C. S. (2004). O desafio do conhecimento: pesquisa qualitativa em saúde. (8a ed.), Hucitec.

Minayo, M. C. S. (2004). O desafio do conhecimento: pesquisa qualitativa em saúde. (11a ed.), Hucitec, 2008.

Ndanga, L. Z. B., Quagrainie, K. K., \& Dennis, J. H. (2013). Economically feasible options for increased women participation in Kenyan aquaculture value chain. Aquaculture, 415: 183-190.

Neves, D. P., \& Medeiros, L. S. (2013). Mulheres Camponesas: trabalho produtivo e engajamento político. Alternativa, 2013.

Oliveira, N. I. S., \& Florentino, A. C. (2018). Avaliação socioeconômica dos piscicultores do município de Porto Grande, Amapá, Brasil. Ciência e Natura, 40, 31.

Nunan, F., \& Cepić, D. (2020). Gestão conjunta de mulheres e pescas: limites à participação no lago Victoria. Fisheries Research, 224, 105454.

Perrot, M. (2015). Minha história das mulheres. (2a ed.), Contexto.

Rahman, M. A., Ferdous, J., \& Tasnim, Z. (2019). Role of women in pond fish farming and fish consumption situation in a selected area of Bangladesh. Archives of Agriculture and Environmental Science, 4(2): 206-212.

Shah, R. H., \& Bukhari, R. (2019). Strengthening the role of women in fisheries and aquaculture. Journal of Entomology and Zoology Studies, 7(3): 648-654.

Simonian, L. T. L. (2005). Pescadoras de camarão: gênero, mobilização e sustentabilidade na ilha Trambioca, Barcarena, Pará. Boletim do Museu Paraense Emílio Goeldi. Série Antropologia, Belém.

Yin, R. K. Planejamento e métodos. (4a ed.), Brookman, 2010.

Wedig, J. C., \& Menasche, R. (2013). Campesinato, festas de família e significados do parentesco. Revista de Antropologia e Arqueologia, 1(1), 150-172.

Tsige, M., Synnevåg, G., \& Aune, J. B. (2020). Gendered constraints for adopting climate-smart agriculture amongst smallholder Ethiopian women farmers. Scientific African, 7, e00250. 